\title{
Perspectives of Healthy Eating Environment on Campus: A Qualitative Study in a Private University in Ankara, Turkey
}

\author{
Kampüste Sağllklı Beslenme Ortamına Yönelik Algllar: Ankara/Türkiye’de Özel Bir Üniversitede \\ Yapılan Nitel Araştırma
}

\section{Z. Begüm Kalyoncu', Özlem Çetiner², Tuğçe N. Balcı ${ }^{3}$ Zeynep B. Eroğlư ${ }^{4}$ Türkan Kutluay-Merdol ${ }^{5}$}

Geliş tarihi/Received: 15.09.2020 • Kabul tarihi/Accepted: 28.11.2020

\begin{abstract}
Aim: Universities provide food service to not only students, but also to their employees from all levels. However, the limited literature persists in terms of evaluating the campus food environment by different kinds of stakeholders. Therefore, this study aims to understand and conceptualize the experiences and perceptions of students and university staff towards campus food environment.

Subjects and Methods: We conducted six focus groups among sixty-four people that belong to a private university in Ankara with the following roles; (i) Turkish and international students, (ii) Academic staff, (iii) Administrative staff, and (iv) Support staff. Thematic analyses were conducted by NVivo software and triangulation is done by evaluating a monthly lunch menu of the cafeteria with Nutrient Rich Food Index 9.3 (NRF 9.3) nutrient profiling model.

Results: Qualitative analyses revealed that participants were aware of the nutritional importance of food services and consequences of consuming meals, foods, and beverages with low nutritional value. Nutritional value of the food was among the most important drivers of food selection and participants demanded menus to be planned by a dietitian. The seven overarching themes that were determined within the qualitative analysis were; (i) administrative process, (ii) nutritional value, (iii) variety, (iv) taste-flavor, (v) hygiene and food safety, (vi) intercultural inclusiveness, and (vii) price. NRF 9.3 scores of the campus lunch menu alternatives were low (ranged from 0.09 to 3.19) in a way that triangulated the qualitative findings.

Conclusion: This study shows that nutritional value and variety of the food and beverage services is a main driving factor for food selection and participants' experiences even more than price and taste of the food. The results highlight the importance of serving healthy menus to all the stakeholders of a university, which could best be achieved by employing dietitians.
\end{abstract}

Keywords: Qualitative research, focus groups, food services, menu planning, universities

1. İletişim/Correspondence: Atıllm Üniversitesi Sağllk Bilimleri Fakültesi Beslenme ve Diyetetik Bölümü, Ankara, Türkiye

E-posta: begum.kalyoncu@atilim.edu.tr • ๑ https://orcid.org/0000-0001-6208-3540

2. Atulım Üniversitesi Sağllk Bilimleri Fakültesi Beslenme ve Diyetetik Bölümü, Ankara, Türkiye • ๑ https://orcid.org/0000-0001-9872-416X
3. Atılım Üniversitesi Sağllk Bilimleri Fakültesi Beslenme ve Diyetetik Bölümü, Ankara, Türkiye • • 은tps://orcid.org/0000-0002-0569-2486

4. Atılım Üniversitesi Sağlık Bilimleri Fakültesi Beslenme ve Diyetetik Bölümü, Ankara, Türkiye • — https://orcid.org/0000-0002-5594-9630

5. Atılım Üniversitesi Sağlık Bilimleri Fakültesi Beslenme ve Diyetetik Bölümü, Ankara, Türkiye • • ㄴ https://orcid.org/0000-0002-0783-947X 


\section{ÖZET}

Amaç: Üniversiteler sadece öğrencilere değil, aynı zamanda her kademeden çalışana da yemek hizmeti sunan kurumlardır. Ancak mevcut literatürde üniversite kampüsündeki beslenme ortamının bu hizmetten faydalanan farklı paydaşlar tarafından değerlendirildiği çalışma sayısı kısıtlıdır. Bu nedenle bu çalışma, öğrencilerin ve üniversite personelinin kampüs beslenme ortamına yönelik deneyimlerini ve algılarını anlamayı ve kavramsallaştırmayı amaçlamaktadır.

Bireyler ve Yöntem: Ankara’da özel bir üniversiteye bağlı altmış dört kişi ile gerçekleştirilen odak grup görüşmelerindeki katılımcılar; (i). Ulusal ve uluslararası öğrenciler, (ii) Akademik personel, (iii) İdari personel ve (iv) Destek personelidir. Tematik analizler NVivo yazılımı ile yapılmış ve Nutrient Rich Food Index 9.3 (NRF 9.3) besin örüntüsü profili algoritması ile kafeteryanın bir aylık öğle yemeği menüsü değerlendirilerek üçgenleme yapılmıştır.

Bulgular: Niteliksel analizler katılımclların yemek hizmetlerinin beslenmedeki önemine ve besin değeri düşük yiyecek ve içecek tüketiminin sonuçlarına dair farkındalıkları olduğunu ortaya koymuştur. Menülerin besin değeri, yemek seçimindeki en önemli belirleyicilerden biri olmakla birlikte katılımcılar, menülerin bir diyetisyen tarafından planlanmasına ilişkin taleplerini dile getirmişlerdir. Nitel analiz sonuçlarına göre belirlenen yedi kapsayıcı tema; (i) idari süreç, (ii) besin değeri, (iii) çeşitlilik, (iv) tat-lezzet, (v) hijyen ve besin güvenliği, (vi) kültürler arası kapsayıcılık ve (vii) fiyat olmuştur. Kampüs öğle yemeği menü seçeneklerinin NRF 9.3 skorları da nitel bulguları destekleyecek şekilde düşük (en az 0.09 ile en çok 3.19 arasında) bulunmuştur.

Sonuç: Bu çalışma, yiyecek ve içecek hizmetlerinde besin değeri ve çeşitliliğinin katılımcıların yiyecek seçimi ve deneyimleri için fiyat ve tattan daha baskın belirleyici faktörler olduğunu göstermektedir. Sonuçlar, bir üniversitenin tüm paydaşlarına sağlıklı menüler sunmanın önemine dikkat çekmekte ve bu sebeple bu kurumlarda diyetisyen istihdamının gerekliliğini vurgulamaktadır.

Anahtar kelimeler: Nitel araştırma, odak grup görüşmeleri, toplu beslenme hizmeti, menü planlama, üniversiteler

\section{INTRODUCTION}

Individuals are increasingly using the workplace cafeterias, canteens, and nearby restaurants on work days for at least one major meal $(1,2)$. Similarly, university students also use campus cafeterias for reasons diverse as distant location of the campuses, intensity of course schedules, and limited financial opportunities. In addition to getting an education, students' social life and well-being related to food consumption significantly affects their experiences in university campuses (3). Especially in private institutions that receive governmental aid in Turkey, where minimum $15 \%$ of the students need to be on full scholarships (4) and many other university students study with full or partial scholarships; the food services could either function to bridge the gap between students coming from differing socioeconomic and cultural backgrounds or further exacerbate the subgroup differences (5). Aside from the price-related concerns; dissatisfaction stemming from inadequate hygiene, lack of nutritious food and variety, unsavory meals, long checkout queues, etc. could lead to avoidance of foods and beverages that are offered on-campus (6-8). Dissatisfaction, content, and quality of on-campus foodservice operations not only affect the health of university students, but also affect the academic, administrative, and support (i.e. cleaning, security, gardening, etc.) personnel's health and job satisfaction (9). Therefore, providing an affordable, healthy, hygienic, and balanced food environment should be a top priority of the university managements both for the students and for their employees (10).

Additionally, since Turkey Council of Higher Education removed an upper quota for international students other than faculties of medicine and dentistry in 2019, Turkish universities are becoming increasingly attractive for international students (11). Thusly, the 
growing presence of international students should also be taken into account and universities that position themselves to be internationally-oriented should put an additional effort into making the food environment as inclusive as possible for diverse cultures.

Considering the significant relationship between productivity of the institution and satisfaction regarding campus foodservices; students' and employees' satisfaction levels ought to be monitored periodically through evaluating the physical environment and the quality of the meals served, as well as the adequacy of the cafeteria staff $(12,13)$. Since a foodborne illness outbreak could harm the image of institutions in a relatively short time, the food services of the universities are mostly inspected according to international scale food safety systems such as Hazard Analysis Critical Control Point (HACCP) and International Organization of Standardization 22000 (ISO 22000) (2). In an International Labor Organization (ILO) report, titled "Food at Work: Workplace Solutions for Malnutrition, Obesity and Chronic Diseases”, inadequate and/or unbalanced nutrition in the workplace was found to reduce the health and productivity of employees up to $20 \%$ (14). Therefore, university stakeholders' satisfaction with food service need to be assessed and dietitians need to be employed for ameliorating the nutritional value of the food environment on campus.

Despite the existence of a sufficient body of quantitative evidence on the sub-optimum nutritional value of meals through food composition data sources and computation systems (15), qualitative understanding of the consumer experiences with regards to food environment in universities are limited. Qualitative research methods are more effective when the aim of the study is to generate in-depth information about consumers' experiences since the results from well-analyzed qualitative studies have a quality of “undeniability" when respondents' verbatim quotes are organized under concrete themes (16). The findings obtained through qualitative research have often proved to be more convincing to policymakers and managers. Additionally, ameliorating the food systems and service quality in line with the needs and expectations of the target audience while focusing on healthy nutrition environment would enable both psychological and social satisfaction beyond meeting the physiological needs of the individuals (17). Therefore, to address the current limitations in food service literature, this study aimed to evaluate the satisfaction and perception of the students (national and international) and staff (academic, administrative, and support) of a private university in Ankara regarding the food and beverage services and whether the nutritional environment on campus encourages healthy nutrition. A secondary aim of the study was to seek insights on possible intervention strategies for enhancing the campus food environment that engender adequate and balanced nutrition. Improvements in these services resulting from this study's results would play a major role in promoting adequate and balanced diet in the university.

\section{SUBJECTS AND METHODS}

The field work of the present qualitative study was carried out between February-March 2020 at a private university in Ankara, Turkey. Further quantitative analyses of the lunch menus were carried out for triangulation purposes (Figure 1).

\section{Food and Beverage Services of the University}

Food and beverage services of the private university was provided by the same enterprise since 2000 . The enterprise has cafeterias at the selected faculties, two cafes, one restaurant, multiple canteens, and vending machines throughout the campus. Table d'hote dishes are prepared at a central kitchen based in the largest building in campus and meals are distributed to the faculties with cafeterias at noon, on weekdays. The university table d'hote cafeterias only offer lunch service to the consumers. Those who want to have breakfast could buy bagels (simit), savory pastries (poğaça), toast from canteens and sandwiches, cakes, biscuits, chocolate, and other snack alternatives found in vending machines. Since no dietitian has 


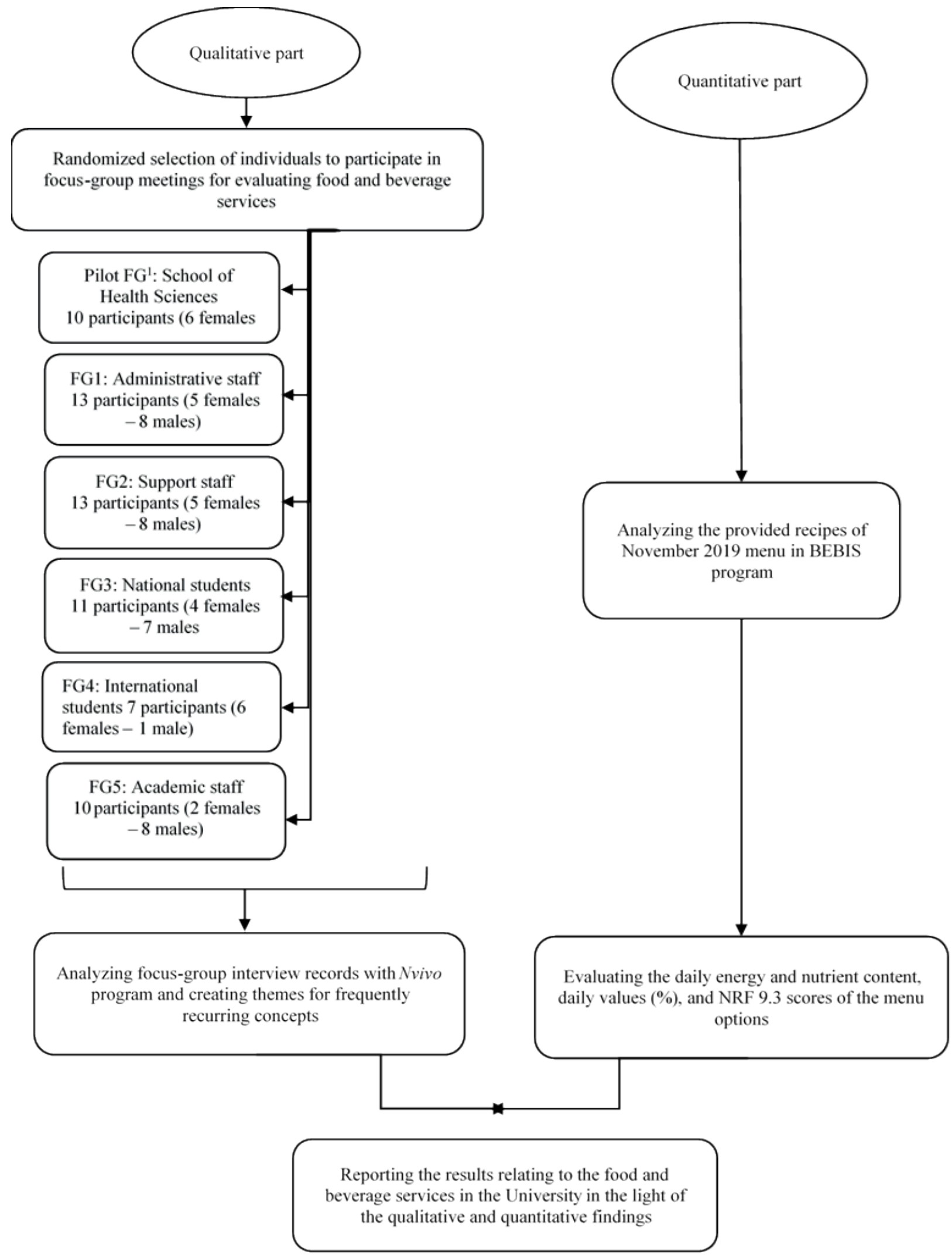

Figure 1. Flow diagram of the study design ${ }^{1} F G$, Focus Group 
been employed neither in the administrative staff of the enterprise nor in the university; menus and food and beverage services are not regulated under the control of a dietitian.

\section{Qualitative Study Design}

In order to evaluate the satisfaction of students and employees regarding food and beverage services, six focus group discussions were held. The focus groups discussions were held separately with students from Turkey and international students along with academic, administrative, and support staff. In both student groups, there were students with and without scholarships from different faculties. Potential participants from all the faculties were informed in detail about the study and they were invited for focus group discussions via sending e-mails. The first focus group meeting was determined as a pilot study and was conducted with the academic staff of the Faculty of Health Sciences of the university. Each focus group discussion was held with 7-12 participants and lasted about 60 minutes. The discussions were held in the meeting room of the Faculty of Health Sciences. At the beginning of each focus-group discussion, the participants were informed about the study again and their consent for researchers to use voice recorders were obtained as well. Participants were ensured about the anonymity of the analysis and reporting process. In each focus-group discussion, the same semi-structured focus group guide was used (Appendix 1).

In order to facilitate the understanding of the questions and build rapport among the participants, four sets of photographs related to various foods (fish, nuts, fruit plate, etc.) and catering services (vending machines, dining hall, etc.) were provided to the participants.

Focus-group audio recordings were transcribed verbatim and imported into NVivo Release version 12-QSR International for qualitative data analysis (18). Themes and categories were created by inductive thematic analysis within the scope of the study. Four researchers (ZBK, TNB, ZBE, OC) familiarized themselves with the qualitative data. Initially, line by line coding was done on Microsoft Word then another coding step was done with the software for integrating separate codes from each focus-group discussions. Two researchers used (ZBK, TNB) open coding independently for all the transcripts, and came together to discuss and merge the codes that they had assigned. Researchers agreed on a set of codes and formed their descriptions (Appendix Table 1).

The coding process was finalized through inductive reasoning, and words, statements and paragraphs related to the broad domains of the interview guide were extracted. Through this in-depth analysis, similar excerpts were identified using the same code. Codes were either single words (e.g., hygiene, taste, quality) or short phrases (e.g., inflexibility of menus, carbohydrate overload, meal scholarship) that captured the essence of the excerpts. Subcategories were further developed to explain the categories more in depth. The comprehensive content analysis obtained as a result of the focus-group discussions was interpreted together with the quantitative results and the triangulation method was completed.

\section{Design of the Quantitative Part}

In order to triangulate the findings from the focus group discussions, monthly lunch menu before the beginning of the study (November 2019 / 21 work days) was selected to be evaluated for its energy and nutritional content. Since there were different meal options for lunch at the university cafeteria; usually one option for soup, two options for the main course (one with meat and one without meat), two options for pasta/rice/pastries, and three options for salads-fruits/ desserts/drinks; 12 different menu combinations were analyzed. However, one day was excluded from the analyses since there was no meatless main course option on that day. In total, 12 different menu options for 20 consecutive days were evaluated in terms of energy, macro and micronutrient contents. Furthermore, menu combinations were evaluated with internationally validated Nutrient Rich Food Index 9.3 (NRF 9.3) nutrient profiling model (19). 
The different menu options were analyzed using the Nutrition Information System (BeBiS, v8.2) (20) program with the standardized recipes requested from the enterprise. Each menu was analyzed both with and without salt to see the effect of salt in sodium content and NRF 9.3 scores. The bread that is served with meals was not included in the analysis. The nutrient content calculations were transferred to IBM SPSS 25.0 software to conduct the analyses (21). The ability to meet the nutrient requirements of different menu options for all age groups reflecting the general population of the university (18/19-50/51-64/65-70/70+) were evaluated using Turkey Dietary Guidelines (TUBER) (22). Dietary Reference Intake (DRI) values were used for evaluating niacin and zinc requirements for men, and niacin, zinc, and iron requirements for women. TUBER was used as the primary choice of nutrient analysis since the requirement amounts were presented according to the needs of Turkish population. However, since niacin requirement has been calculated based on the total energy intake, and zinc requirement has been determined based on total phytate intake in diet in TUBER, DRI values were used. Additionally, in TUBER iron requirements of women were determined separately according to the premenopausal and postmenopausal stages. However, menopause age varies in women and since the assignment of an average iron requirement may not meet the needs of women in Turkey, where iron deficiency is common (22). Therefore, the use of DRI values were deemed more appropriate as they provide nutrient requirements for age and sex independent from total energy, phytate intake, and menopausal stage (23). Upper limit (UL) values for sodium, saturated fatty acids, and sucrose were also used to evaluate the content of different menu options (23). The NRF 9.3 algorithm developed by Drewnowski et al. (19) was used to evaluate the nutritional pattern profile. The scoring system of this algorithm was calculated based on the daily values of protein, fiber, vitamin A, vitamin C, vitamin E, calcium, iron, potassium, magnesium, saturated fat, added sugar and sodium. In the calculation phase of this model, meals were evaluated according to their nutrient content per $100 \mathrm{kcal}$.

\section{Quantitative Data Analysis}

Energy and nutrient content of each option were provided as mean $(\overline{\mathrm{X}})$ and standard deviation (SD) for parametric data; median and min-max values for non-parametric data. The ability of meeting the daily energy and nutrient requirements of each menu option was provided as percentage (\%) for each age group. While calculating these percentages, $2 / 5$ of daily energy and nutrient requirements of each age group were taken into consideration (17). Energy and nutrient content comparisons between menu options with and without meat were determined by $T$ test for parametric data and Mann-Whitney $U$ test for nonparametric data. Statistical significance was set at $\mathrm{p}<0.05$ for all tests.

\section{Ethical Approval}

The present study was approved by the Atilim University Human Research Ethics Board (Decision Number: 59394181-604.01.02-3087).

\section{RESULTS}

\section{Qualitative Results}

Result of the qualitative analysis revealed seven themes and a number of categories under each theme. Detailed information of these themes and categories along with their related verbatim quotations from focus group interviews were summarized in Table 1. However, some names have been taken out from the quotations in order to protect participants' anonymity.

\section{Results of the Quantitative Analysis}

The average energy and nutrient content of menu options both with and without meat were demonstrated in Table 2. The menu options with meat had an average of $1028 \pm 229 \mathrm{kcal}$ energy content, whereas, menu options without meat had an average 
Table 1. Themes, summaries of categories and verbatim quotes generated from comprehensive content analysis of the focus group interviews.

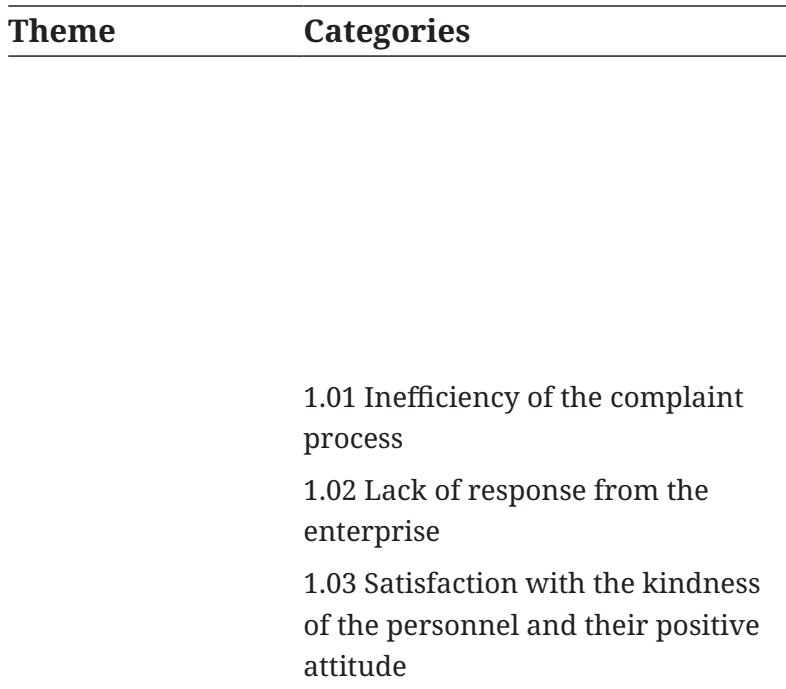

Verbatim Quotations

... "When we present our suggestions to them, they respond with very interesting reactions. For example, one day, they serve it often, there was Mucver ${ }^{1}$ dish (24). It was coal-black, it was so black as soot that is fried too much or kept in oil, most of the friends hesitated to take it because it was too oily and I did not get it either. I said, can't you do this another way? Do you have to fry it in the oil, it could also have made on an oven tray? He said, "Mucver could not be cooked in an oven tray". I know it is not, but it could be done, there is no such thing, no rule as it could not be done like that, people do not do it that way, but could be done. We also make it at home, because I also cook myself, so I know it. " $\left(\mathrm{FG}^{2} 5\right.$, male)

... "The operating capability of the firm is not good, there are some bad features about both the selected personnel and the service provided since the operating capability is not good." (FG 2, male)

... "And the canteen here ... We stay here until 5-6 pm, most of the time, it closes 1.04 Sub-optimum qualifications of at 4 pm, we will eat something now, we do not know what to do." (FG 1, female) the enterprise personnel

1.05 Enterprise management's operational capability

1.06 Limited working hours of the cafeterias

1.07 Demands for more intense

1.0 Administrative process control of the university administration

1.08 Demand for employment of a dietitian

1.09 Low business potential across the campus

1.10 Comparisons with other universities

1.11 Support for entrepreneurial students

1.12 Distance to cafeterias

1.13 Limited socialization opportunity

1.14 Concerns on price differences

1.15 Demand for meal scholarship

1.16 Limited income students
... "I can't have lunch on Mondays at all, just pretzels etc. Because the lesson ends at 11:30 am and I have a half-hour break, class starts again at $12 \mathrm{am}$. That's why I go hungry” (FG 3, female)

... "As far as I know, there is no dietitian currently on the staff. I think this is a huge drawback!” (FG 5, female)

... "Prices are really a problem for every university member here. But I think the main problem here is a little bit of management. Because it's called monopoly. There is no other option. No matter how much the prices increase, I have no other choice but to bring from home. So, first of all, I think we should first overcome this monopoly logic rather than the quality of food." (Pilot FG, male)

... "A person from another university's management said to a friend of mine, "the owner of our university could not even feed his staff". Obviously, this was a very unfortunate sentence that caught my attention. I also think the price is expensive. (FG 5, male)

... "In terms of personnel, I think it would be better for all staff to eat for free or if it is 3.5 Turkish liras, for that price. Because in all the universities I have seen, staff either eats for free or if there is a significant amount, everyone eats for the same price. In other words, there is no such thing like paying according to the academic title, or for his work. Therefore, I think it is beneficial to remove this difference." (FG 1, male)

... "The solution suggestions we found due to the discomfort we feel about food unavailability is also unhealthy. I mean, I don't find eating from tupperwares in the rooms to be very humane for me. Because what we call food is an important thing and it is a tool for socialization within the institution. Because in comfortable environments, in large spaces, you can greet people that you do not know while walking on that road, then in cafeteria, so here the main way people socialize in this institution is service buses. If you take the bus, you know a lot of people, if you do not take the bus, you don't know anyone because you don't have a socializing environment like a dining hall.” (Pilot FG, female)

\footnotetext{
${ }^{1}$ Mucver is a traditional dish that is made by frying a dough that includes grated zucchini, eggs, flour, dill, and onion

${ }^{2}$ FG, Focus Group
} 
Table 1. Continued

\begin{tabular}{|c|c|c|}
\hline Theme & Categories & Verbatim Quotations \\
\hline & & $\begin{array}{l}\text {... "Apart from that, as I said, there must be something to show the nutritional values } \\
\text { and they must really have a dietitian because friends say that too, we don't really } \\
\text { know what they use in there and what they do. It just comes in front of us and when } \\
\text { it is cooked, it reaches a certain shape, you cannot understand what is in it, you do } \\
\text { not have much professionalism on that subject. Therefore, there should definitely } \\
\text { be a dietitian or a person who would control the place in terms of both hygiene, } \\
\text { nutritional quality and taste." (FG 5, female) } \\
\text {... "In another university, my father had a cafeteria and there was a dietitian who } \\
\text { was constantly inspecting. Even if they were like brothers with my father, he was } \\
\text { easily saying it loud to him if there were nutrition and hygiene problems. He could do } \\
\text { this, but I didn't see anyone here yet." (FG 3, male) }\end{array}$ \\
\hline & $\begin{array}{l}\text { 2.01 High carbohydrate and fat } \\
\text { content }\end{array}$ & $\begin{array}{l}\text {... "My wife, also, sometimes says to me "why are you hungry, don't you eat well?", } \\
\text { because I go home hungry." (FG 1, male) }\end{array}$ \\
\hline & $\begin{array}{l}\text { 2.02 Demand for nutritional content } \\
\text { 2.03 Body weight increase due to } \\
\text { cafeteria food } \\
2.04 \text { Feeling unsatiated perpetually } \\
2.05 \text { Limited healthy options for } \\
\text { vegetarians }\end{array}$ & $\begin{array}{l}\text {... "I had not been eating meat for five years before (err) because of my own health } \\
\text { problems, I started eating meat for about six months. Before, I was in a lot of trouble } \\
\text { in the cafeteria because there is a situation like this, my friend knows, according } \\
\text { to the menu, it says "stuffed peppers" and I went with great enthusiasm to eat and } \\
\text { said "yay!", stuffed peppers, and I really put it on my table. Later, when I saw that } \\
\text { there was ground beef in it, I was so sad! ... Actually, that's why I haven't eaten for a } \\
\text { long time. I normally eat very rarely, but I always get hungry, my work is very busy, }\end{array}$ \\
\hline & $\begin{array}{l}2.06 \text { Not complying with the } \\
\text { principles of menu planning }\end{array}$ & $\begin{array}{l}\text { I definitely have to eat a meal, but (err) I get in between because there is broth. For } \\
\text { example, because the rice is more like mush, I have no idea whether they have meat }\end{array}$ \\
\hline & $\begin{array}{l}2.07 \text { Similar foods were offered in } \\
\text { the same menu }\end{array}$ & $\begin{array}{l}\text { broth in our school or they transfer it from the meat juice they made that day and I } \\
\text { think this should be stated clearly." (FG 1, female) }\end{array}$ \\
\hline \multirow[t]{12}{*}{ 2.0 Nutritional value } & $\begin{array}{l}\text { 2.08 Lack of variety of nutrients and } \\
\text { a balanced meal }\end{array}$ & $\begin{array}{l}\text {... "Why would you give bulgur pilaf next to stuffed peppers?” (FG 2, female) } \\
\text {... "Let me tell you what my friends want to convey to me. Well, two rice at the }\end{array}$ \\
\hline & $\begin{array}{l}2.09 \text { Concerns about the nutritional } \\
\text { value of foods }\end{array}$ & $\begin{array}{l}\text { same time. Two pastas, for example. Pasta comes out all the time. We want to eat } \\
\text { differently." (FG 2, male) }\end{array}$ \\
\hline & $\begin{array}{l}\text { 2.10 Cooking methods } \\
2.11 \text { Amount of fat }\end{array}$ & $\begin{array}{l}\text {... "Ma'am broccoli salad comes out sometimes, it is very cooked, I think its vitamin } \\
\text { is gone when they boiled that much. I don't know if I'm wrong, but I think everything } \\
\text { should be cooked properly. If we are going to get vitamins from it, it should be cooked }\end{array}$ \\
\hline & $\begin{array}{l}2.12 \text { Intensive use of foods with } \\
\text { high carbohydrate content }\end{array}$ & $\begin{array}{l}\text { adequately. The vegetables are cooked to death, I mean, salads that served are soggy } \\
\text { and dull." (FG 2, female) }\end{array}$ \\
\hline & $\begin{array}{l}2.13 \text { The high sugar content of } \\
\text { packaged products }\end{array}$ & $\begin{array}{l}\text {... "There is nothing we can buy in vending machines anyway. The vending machine } \\
\text { seems completely blank when I pass it through a small selection. Only water is }\end{array}$ \\
\hline & 2.14 Demand for healthier foods & $\begin{array}{l}\text { visible on the vending machine. I think something can be done in this regard.” (FG } 4 \text {, } \\
\text { male) }\end{array}$ \\
\hline & 2.15 Healthier breakfast options & ... "Some of the items or foods have a lot of sugar or salty so I think if we find a \\
\hline & $\begin{array}{l}2.16 \text { Healthy meal options for } \\
\text { individuals with chronic diseases }\end{array}$ & $\begin{array}{l}\text { machine which sells some fruits for example or some vegetables be better than } \\
\text { having a snacks or sweets in the morning for example” (FG 3, female) }\end{array}$ \\
\hline & & $\begin{array}{l}\text {... "During my } 3 \text { years of working, I did not see any fish in the menu. I think there is } \\
\text { something missing for this place" (FG 1, male) }\end{array}$ \\
\hline & & $\begin{array}{l}\text {... "There really has to be variety in the morning. Not only simit, pastry, but also } \\
\text { cheese, olives, and if necessary, alternatives such as tomato and pepper should be } \\
\text { provided. It should definitely be like this." (FG 3, female) }\end{array}$ \\
\hline & & $\begin{array}{l}\text {... "I mean; I haven't eaten the table d'hote menu for about } 2 \text { years. But I have eaten } \\
\text { a few times before that and I had a stomach ache. I also have Type } 1 \text { diabetes, so I } \\
\text { don't think it's too good either." (FG 3, male) }\end{array}$ \\
\hline & & $\begin{array}{l}\text {... "The price for administrative staff is okay, I could eat it if I didn't have any health } \\
\text { problems.” (FG 1, male) }\end{array}$ \\
\hline
\end{tabular}


Table 1. Continued

\begin{tabular}{|c|c|c|}
\hline Theme & Categories & Verbatim Quotations \\
\hline 3.0 Variety & $\begin{array}{l}\text { 3.01 Limited options on campus } \\
\text { cafeterias } \\
\text { 3.02 Monotonousness of the table } \\
\text { d'hote menu } \\
\text { 3.03 Presence of only one enterprise } \\
\text { on the campus } \\
\text { 3.04 Demand for new businesses } \\
\text { serving in different areas }\end{array}$ & $\begin{array}{l}\text {... "For one month, maybe I don't know if the menu list comes to you (to the } \\
\text { moderator), maybe it's been the same for the last five years. Take a look, ma'am. } \\
\text { Of course, so does such a thing happen. It is always the same thing for a month... } \\
\text { Chicken that has been prepared is something, well, it is Monday; sour chicken. } \\
\text { Another sour chicken coming on Tuesday. Wednesday is the other... So it is shifting, } \\
\text { nothing else. Oh, and Mashallah! they have a lot of chicken varieties. Thousands of } \\
\text { them!” (FG 2, male) } \\
\text {... "The soup is also obvious, there are } 3 \text { kinds of soup, always the same soup." (FG 1, } \\
\text { female) } \\
\text {... "There is such a monopoly here as it is not open to companies from other places } \\
\text { anyway. Therefore, we have to be content with whatever this place gives.” (FG } 3 \text {, } \\
\text { male) } \\
\text {... "I prefer outside the campus because inside the campus we don't see any } \\
\text { competitions between ... for example departments but outside the campus we see } \\
\text { many competitions between the restaurants that's why quality is better than the } \\
\text { quality inside the campus." (FG } 3 \text {, female) }\end{array}$ \\
\hline
\end{tabular}

... "At first, I think vegetable meals are far from success. So they are far from flavor. So I cannot eat here vegetables properly. You need to eat something like meat all the time. In other words, people around me generally think that many dishes are tasteless. Of course we do not know the reason for this. We have no idea what it's all about, is it the cooks or what?" (FG 5, male)

4.01 Lack of taste in meals

4.02 Unappetizing taste

4.03 Similar flavors

4.0 Taste and flavor

... "All the food is very interesting, it's like we're eating sponges. You can't eat for the second time; you leave it on the second fork." (FG 3, female)

... "There is a subject like this. Waste. So, there is a lot of waste because of this. And it is a sin. I think ... when I look at the trays, whichever the plate you look at, half of the food is usually thrown away. As they say, if you give it to a dog, dogs won't eat it either. It goes to waste, it is a sin, it becomes a sin, in my opinion. You know if there was something delicious, if people eat and leave fulfilled. Why would it go to the trash? All the money, expense and effort. Why should I?" (FG 2, female)

... "I can cook (she laughs) but there is no time seriously I cannot find time and I don't like to take cold food you know and you take it back from home, so mostly breakfast at home sometimes I just to have to stay fasting until I go back" (FG 4, female)

... "We don't eat for example chicken doner outside, people disdain it because it costs 3.5-5 Turkish liras. But that chicken doner... We see that when it comes out here, like a wedding like a feast, everybody is plundering because there is chicken doner. Sometimes food is not even enough" (FG 2, male)

of $861 \pm 192.6 \mathrm{kcal}$ energy content. In both options, the percentage of fat in total energy of the lunch menus was higher than the recommended amounts $(43 \%$ for menus with meat, $42 \%$ for menus without meat) (Appendix Figure 1). Both fat and protein content of the menus were significantly higher in options with meat ( $\mathrm{p}<0.001$ for both fat and protein content), whereas, carbohydrate content was similar among menu options ( $p=0.545$ ) (Table 2). Nevertheless, the fiber content of the menu options without meat was significantly higher than the ones with meat (12.7 vs 14.5, $\mathrm{p}=0.002$ ). In both menu options, omega-3 fatty acid content was nearly " 0 ”, which indicated an absence of rich sources such as fish or soybean in menus. On the other hand, both menu options had a higher saturated fatty acid content than the recommended amounts, options with meat having significantly higher values (12.5 vs 9.4, $\mathrm{p}<0.001)$. 
Table 1. Continued

\begin{tabular}{|c|c|c|}
\hline Theme & Categories & Verbatim Quotations \\
\hline $\begin{array}{l}5.0 \text { Hygiene and food } \\
\text { safety }\end{array}$ & $\begin{array}{l}\text { 5.01 Adequate food service hygiene } \\
\text { compared with past measures } \\
5.02 \text { Use / lack of use of protective } \\
\text { equipment (bonnet, gloves, masks) } \\
\text { 5.03 Non-food items in meals } \\
\text { 5.04 Technical perspective with } \\
\text { a personnel experience on food } \\
\text { service }\end{array}$ & $\begin{array}{l}\text {... "There were no windows in our old cafeteria. It was a dark and cold place, cold } \\
\text { as ice. Pardon to say, the rats were running around, you know. The place stank, the } \\
\text { windows were already covered with spider webs. We are now eating at the cafeteria } \\
\text { at least at floor -2. At least there are windows, we can see outside. Or you can find } \\
\text { it clean or you can find sitting place. At least otherwise, you couldn't find a place to } \\
\text { sit, the place was too dirty. But here again, as we will really talk about its positive } \\
\text { aspects, it is clean. The windows, at least the windows, we can sit and be treated } \\
\text { like people. We were not treated like people there. It is both ice cold and very dirty. } \\
\text { At least it's hot in here. You know, you can sit down and eat at the same place } \\
\text { with everyone. There was discrimination there. We were at floor -4, students and } \\
\text { teachers could eat wherever they wanted. Now at least we can all eat in the same } \\
\text { environment. This is a good thing for me." (FG 2, male) } \\
\text {... "I know that there is a cleanliness problem in salads especially in places where } \\
\text { meals are served with table d'hote. We even made a joke at the time. A snail came } \\
\text { out of a salad, and I said something to that student. In France, they pay } 50 \text { euros for } \\
\text { it, you are lucky to eat it for } 10 \text { liras." (FG } 5 \text {, male) } \\
\text {... "But the taste of table d'hote is the same anyway. The school has such a nice } \\
\text { kitchen, but I wish it was used better. There is a hot water place under that table } \\
\text { d'hote or something, if it is heated, the food will remain warm, but this is not used. } \\
\text { There is only water there." (FG 2, male) } \\
\text {... "The grillers where they grill these chickens are truly disastrous. Because } \\
\text { sometimes, my mother has a restaurant like this, I understand that these needs to } \\
\text { be sprayed at night and brush cleaned in the morning, but you know that even the } \\
\text { chicken that is brought in front of you has those fried, burnt pieces for a few days } \\
\text { old." (FG } 3 \text {, female) }\end{array}$ \\
\hline
\end{tabular}

... "Sometimes I see food I don't know what is in it so if they can make like doing something that we know randomly like pizza healthy pizza like they said something traditional we know what is in it exactly so we don't understand exactly" (FG 4,

6.01 Request for different countries’ female)

6.0 Intercultural cuisines

... "I don't think there is one here, but there are students from abroad! They do not inclusiveness

6.02 More international meal options think, only about Turkish food. There is no food from their culture. There are 6 or 7 (international students) in my department, for example, in a lower or upper grade. Why are we imposing Turkish food on them? Okay, our food is good we can introduce this, but we need to think about them (international students)." (FG 3, male)
The vitamin and mineral contents were different among menu options. Vitamins $\mathrm{B}_{1}, \mathrm{~B}_{2}, \mathrm{~B}_{6}$, and $\mathrm{B}_{12}$ content of options with meat were significantly higher ( $\mathrm{p}=0.008, \mathrm{p}<0.001, \mathrm{p}<0.001$ and, $\mathrm{p}<0.001$ respectively), whereas, vitamin $\mathrm{C}$ content was higher in options without meat $(p<0.001)$ (Table 2). Especially, vitamin $\mathrm{B}_{2}$ and $\mathrm{B}_{12}$ content of the options without meat were not able to meet the required amounts for certain age groups (Figure 2). Similarly, iron and zinc contents were also lower in options without meat $(\mathrm{p}<0.001$ for both), with amounts falling under recommendations.
Overall, the calcium content of both menu options was under the recommendations for all age groups (226.1 $\pm 102.4 \mathrm{mg}$ for options with meat, $274.7 \pm 124.7$ mg for options without meat). On the contrary, the sodium content of both options (with salt) was above the recommendations $(2196.8 \pm 484.9 \mathrm{mg}$ for options with meat, $2046.5 \pm 642.7 \mathrm{mg}$ for options without meat) (Table 2). The NRF 9.3 scores of the meal alternatives were calculated with the nine nutrients that were encouraged to be consumed more and three nutrients that were recommended to be limited in the diet, 
Table 1. Continued

\begin{tabular}{|c|c|c|}
\hline Theme & Categories & Verbatim Quotations \\
\hline 7.0 Price & $\begin{array}{l}\text { 7.01 High prices } \\
\text { 7.02 High prices in vending } \\
\text { machines } \\
\text { 7.03 High prices than other } \\
\text { universities } \\
\text { 7.04 Students with challenging } \\
\text { financial situation } \\
\text { 7.05 Lean towards more affordable, } \\
\text { low in nutritional value foods } \\
\text { 7.06 Demand for individual sale of } \\
\text { table d'hote menu options }\end{array}$ & $\begin{array}{l}\text {... "if you take like full meal like in other universities it's too low price in other } \\
\text { university, here it's like eating outside in a restaurant you can pay, the same price } \\
\text { this is one of the points and each semester the meals is getting more expensive!" (FG } \\
4 \text {, female) } \\
\text {... "I agree with all my friends in price. Very expensive. You know, we are a } \\
\text { foundation university, we do not receive government funding. But it is again very } \\
\text { expensive for a private university. We have friends who study with scholarship. } \\
\text { Okay, you get the scholarship, but the cafeteria prices here are already as much as a } \\
\text { scholarship money." (FG 3, male) } \\
\text {... "For example, the students did some research. We do not use vending machines, } \\
\text { but the kids (students) did research on our open-house days, we were the university } \\
\text { that sells the products in vending machines the most expensive." (FG 1, male) } \\
\text {... "Now there are also 100\% scholarship students here. In other words, there are not } \\
\text { only students with a certain amount of income of their father or mother. Therefore, } \\
\text { this includes things other than food, I do not know, transportation and other } \\
\text { things are included, these are all paid here, so that student eats potatoes between } \\
\text { bread because he cannot pay } 15 \text { Turkish liras. So I see. How healthy is this potato } \\
\text { sandwich? Then in the lesson, you expect him listen carefully and to be alert. This is } \\
\text { not possible." (Pilot FG, male) } \\
\text {... "I think it is necessary to increase the variety and I think we have to give a single } \\
\text { price to each product. So as far as I know, ifyou buy a soup, but it is again the same } \\
\text { price, even if it is just a soup." (FG 1, male) }\end{array}$ \\
\hline
\end{tabular}

were ranged between 0.09 and 3.19 with options without meat having higher average scores ( 0.64 vs 0.77) (Appendix Figure 2).

\section{DISCUSSION}

The present study qualitatively evaluated the satisfaction and perception of students and personnel regarding the catering services of a foundation university in Turkey and whether the campus environment was encouraging healthy eating. Additionally, the qualitative findings were triangulated by analyzing the energy and nutrient content of table d'hote lunch menu variations of a selected month along with calculating their NRF 9.3 scores (19). Results from this study showed that all the participants were aware of the nutritional importance of food services and consequences of consuming meals, foods, and beverages with low nutritional value. Despite not having any professional knowledge on nutrition, participants expressed their discontent with meals that were planned without considering the meal planning principles. Participants' opinions on the meals' nutritional inferiority were supported by the quantitative analyses. Additionally, even participants that spent less than one academic year at the university, including international students, could clearly identify problems related to the administrative processes, lack of variety in foods and establishments, and seemingly minor problems of hygiene and food safety.

Overall, participants in this study understood the importance of employing a dietitian in food service administration. Their demand for food and beverage services to be controlled by a dietitian were emphasized by university students and staff for "healthy nutrition". These findings were in agreement with those of Yona et al. (25), who did a comprehensive study in Israel and documented significant nutritional care improvements and cost savings after recruiting food service dietitians in hospital kitchens. Employing dietitians not only resulted in menus to be analyzed in detail per portion, but also waste was reduced and the institutional budget was positively affected (25). Since dietitians are trained professionally in providing 


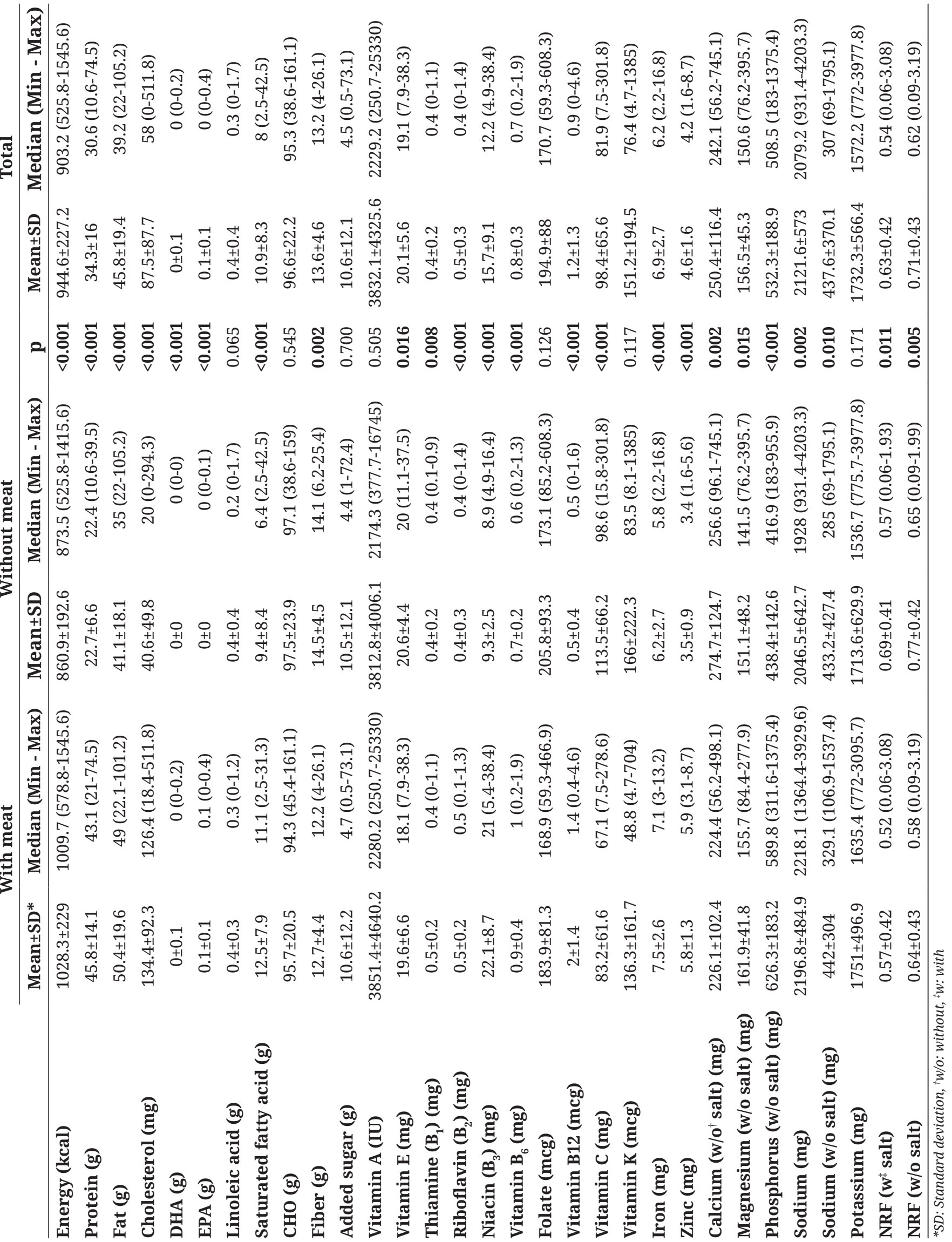



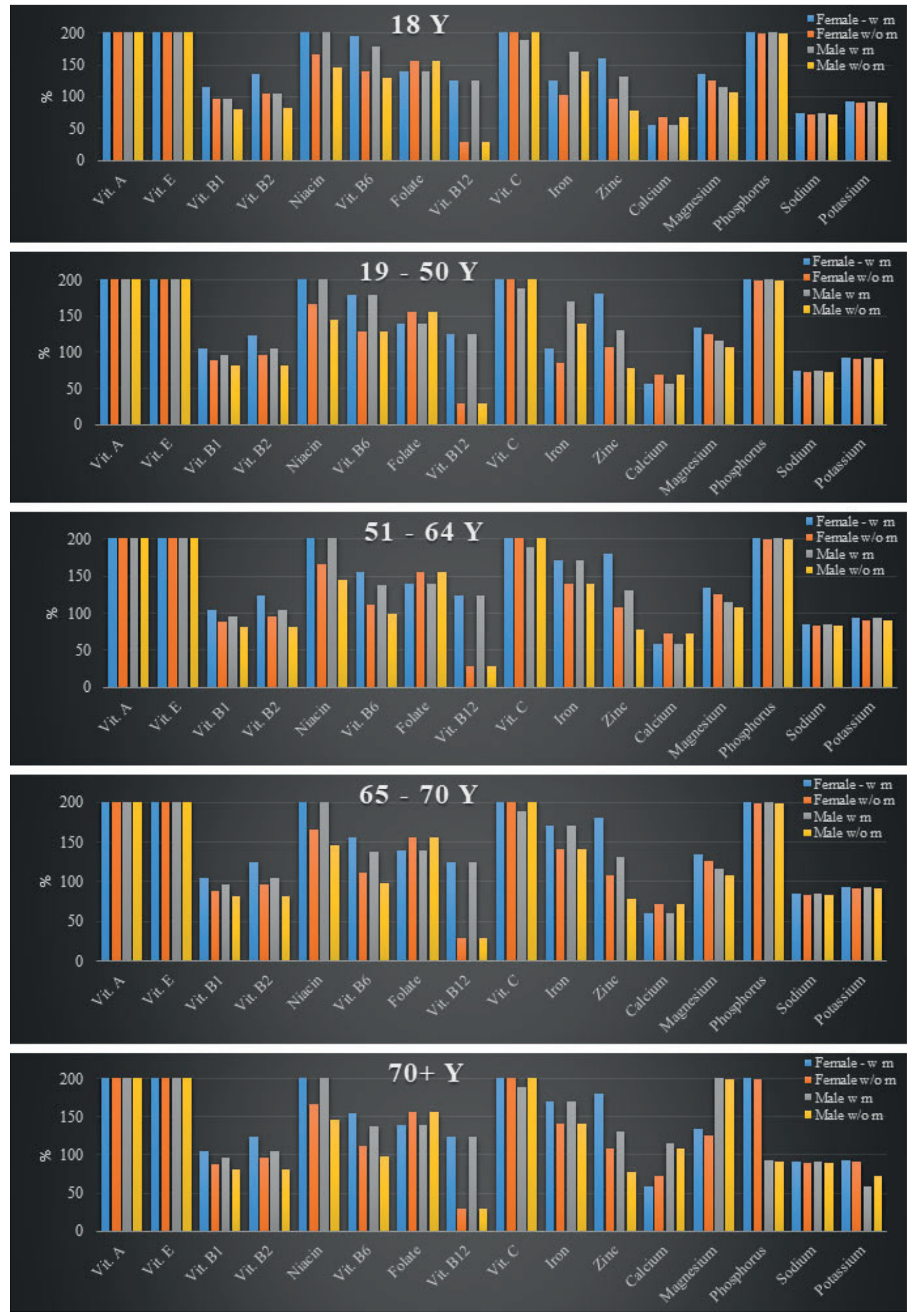

Figure 2. Adequacy of menus (with and without meat) in meeting the vitamin and mineral requirement for lunch (\%) 
adequate, balanced, and safe meals in food services, "food service management" is an important part of the dietetic profession (26). Dietitians have an active role in all processes from planning kitchens to developing new recipes in food service operations (27).

Consistent with the literature, participants of all the focus groups in the present study did point out their concerns about the nutritional content of the food in the cafeterias, canteens, and vending machines above their concerns over price and taste (28).

Although university and workplace vending machines are generally found to be unhealthy with one study from Australia documenting 93\% of the foods to be unhealthy (29), the intense dissatisfaction and refusal of these products by the consumers demonstrates that establishments could no longer saturate campuses with foods that have low nutritional value and high profit margin. Since the role of healthiness in the food choice is continuously increasing in Turkey, Europe, Asia, and North America; highly educated consumers that study and work in a private university, in this study, also demanded healthier alternatives, in agreement with current literature $(30,31)$.

According to an extensive systematic review on healthy nutrition interventions of vending machines, increasing healthy food alternatives and their affordability compared to "unhealthy" ones increased the sales of healthy foods and decreased the sales of unhealthy alternatives unanimously (32). Therefore, increasing the availability of healthier items in vending machines along with reasonable pricing could nudge consumers into buying healthier snacks (33). Deliens et al. (34) also noted that implementing $10 \%$ to $20 \%$ higher prices if students choose French fries in their menus and $10 \%$ and $20 \%$ lower prices if they choose fruit instead of dessert led the participants to opt for healthier alternatives. Similarly, the present study participants demanded more detailed information on the ingredients of the meals as well as energy, protein, fat, and fiber content of the meals per portion in the form of a nutrition label made visible at the point of sale. Since the quantitative analysis of the table d'hote lunch menus revealed high overall fat, saturated fat, and sodium content with low calcium levels along with some meatless options being poor in vitamins and minerals such as iron, zinc, $\mathrm{B}_{2}, \mathrm{~B}_{12}$ and $\mathrm{B}_{6}$; providing nutritional information per portions could encourage the enterprises to serve healthier alternatives that are in line with the nutritional recommendations and consumer demands. The findings of Dikmen and Pekcan's study (15) also support the present study's results in a way that sodium, total fat, and saturated fat content of table d'hote menus of three private and two state universities in Ankara were above Turkey Dietary Guideline recommendations (22). However, the NRF 9.3 scores were found to be lower in the present study than that of Dikmen and Pekcan's study findings (15). The objective nutrient profiling results ensure the trustworthiness of the qualitative findings and indicates an immediate necessity for developing policies that improve healthy eating behaviors across campus.

Furthermore, "lack of variety" was among the top problems that participants mentioned and the monotony created by repetitive menus and foods reduced the consumers' perceptions of quality and satisfaction within an academic year in line with Smith (6) and Kwun's (35) studies. However, it is also noteworthy that in contrast with Lachat et al.'s study (36), the participants did not mention self-discipline or self-control at all as factors that would influence their eating behavior. Therefore, without having adequate self-regulation skills that are indispensable for making healthy decisions and maintaining a healthful life, the demand for increasing the variety of options in the university might not directly translate into healthy eating (36). Also the intense competing demands of academic responsibilities and private institutions' employing less people than governmental universities might put additional strains on the employees, making eating healthy to be a lower priority (37). Since cost and convenience are two factors that drive food choices, increasing the accessibility of fruits and vegetables with an affordable price while not increasing the availability of unhealthy options on campus would increase the odds of healthy food consumption (38). 
Our results further indicate that participants placed a high value on hygiene and food safety. Despite students and staff to be moderately satisfied with the hygiene of the establishment on campus, increasing the visibility of internal and external hygiene inspections, sharing the brands of ingredients, and employing a dietitian would further enhance the food service quality perception that is linked with hygiene among consumers. Unlike the studies that were conducted in Europe and North America (28,39), participants emphasized the importance of hygiene more when asked about the "health of the food environment" in the present study. Emphasizing hygiene as part of healthy food environment could result from either not having enough confidence in their nutrition knowledge or consumers might have a higher distrust in the regulatory frameworks due to university specific factors. Bolek's recent study (40) indicated that Turkish consumers were highly concerned about food safety due to lack of knowledge on the topic and additionally having misconceptions about food processing and preservation methods. Sanlier and Baser (41) also demonstrated the relationship between food safety knowledge and attitude in their recent study that they conducted in Ankara.

Furthermore,internationalstudentswere documented to have their unique problems compared to their Turkish counterparts in a way that their culinary acculturation to Turkish cuisine was low and they could not understand the ingredients of the meals due to their limited language skills. Although international students could acculturate to the culinary culture of the host country, they may feel stressed and seek familiar flavors in nutritional environments $(42,43)$. In our study, the international student participants came from Gulf countries and Africa, and they all expressed intense frustration over having to eat Turkish food without understanding the ingredients of the dishes. One participant mentioned having to fast throughout the day since she thought the food environment was unhealthy. As the participants could not find their traditional spices on campus, they demanded for more international food as well as easy-to-understand alternatives like whole fruits, more salad options, and international breakfast options such as omelet, oatmeal, and smoothies. Campus catering services could play a major role in the adaptation process of international students to the country and have the potential to reduce the stress that may result from homesickness (44). In order to enable that, main ingredients of the dishes could be specified in English at the point of sales and healthy versions of the wellknown international foods could be made available at more outlets along the campus area in order to enhance the intercultural inclusiveness. Accordingly, the planning and revising of dining hall menus by dietitians by taking into account the demands of international students, is seen as an important factor in increasing individuals' commitment to school and their satisfaction (45).

While the present study provided novel insights about the perception of healthy food environment in campus among students and university employees, there were several limitations that need to be mentioned. To begin with, although purposive sampling strategy was used, participants might have decided to participate in the research due to their personal interest and their opinions may not be reflecting the public opinion in general. Secondly, since the study was being conducted at the Faculty of Health Sciences, despite putting every effort to minimize bias by abstaining from leading questions, participants' responses might have been affected by an unintentional desirability bias. Thirdly, because of university specific factors, the generalizability of the study's findings to state universities and universities with less or no international students could be limited. Nevertheless, our study results generated comprehensive data on the perception of different university stakeholders on the healthy food service environment. The findings could be relevant and germane to other schools and many workplaces that offer food service to students and employees with similar characteristics. Our results could provide insights into developing nutritional policies for improving the healthy food environment of university campuses. 
To conclude, ideally food and beverage service should provide adequate, balanced, and safe meals, as well as considering the consumer profile and ensuring diversity. While providing diversity, the factors that affect the consumers' food choices (age, gender, cultural habits, different diet types, etc.) should be taken into consideration. Therefore, consumer demands and satisfaction should be followed regularly for enhancing food services preferably by employing dietitians.

Conflict of interest: The authors declare that they have no conflict of interest.

Funding sources: The study project was funded through a grant from the Atilim University's Undergraduate Research Project Program (Project Code: ATÜ-LAP-1920-04).

Acknowledgements: The authors extend their gratitude to student researchers Yaren Odabaş, Merve Gündoğmuş, Simge Elif Yllmaz, Selin Şahin, Buse Çalışkan, Begüm Onsun, Senanur Soyünen, Zeynep Özcan, Hidaya Alsaadi, and Ecem Hüsmenoğlu for their work on organizing the focus group room, transcription and literature review; as well as Assoc. Prof. Derya Dikmen for her guidance regarding NRF 9.3 related data analysis. The authors also thank the study participants and AZN Catering and Organization for providing the standardized recipes of the selected month.

Authorship: $Z B K$ and $O C$ conceptualized the study. $Z B K, O C$, $T N B$, and ZBE collected and analyzed the data. TKM gave guidance throughout the study. All the authors have reviewed, edited, and approved the manuscript.

\section{KAYNAKLAR}

1. Merdol TK. Toplu Beslenme Servisi (TBS) Sağlıklı Yönetim Rehberi. Ankara: Hatiboğlu Yayınevi; 2015.

2. Osimani A, Garofalo C, Milanović V, Taccari M, Aquilanti $\mathrm{L}$, Polverigiani $\mathrm{S}$, et al. Indoor air quality in mass catering plants: Occurrence of airborne eumycetes in a university canteen. International Journal of Hospitality Management. 2016;59:1-10.

3. Zainol NA, Seladorai J. What matters most? Factors influencing international students' satisfaction towards cafeteria foods. Mediterranean Journal of Social Sciences. 2016;7(4):295-302.

4. T.C. Cumhurbaşkanlığı Mevzuat Bilgi Sistemi - Vakıf Yükseköğretim Kurumları Yönetmeliği. 2005. Available at: https://www.mevzuat.gov.tr/ mevzuat?MevzuatNo= 9768\&MevzuatTur $=7 \&$ MevzuatTertip $=5$ Accessed Oct 30, 2020.

5. Amore L, Buchthal OV, Banna JC. Identifying perceived barriers and enablers of healthy eating in college students in Hawai'i: A qualitative study using focus groups. BMC Nutr. 2019;5:16.

6. Smith RA, White-McNeil A, Ali F. Students' perceptions and behavior toward on-campus foodservice operations. International Hospitality Review. 2020;34(1):13-28.

7. Saglik E, Gulluce A, Kaya U, Ozhan C. Service quality and customer satisfaction relationship: A research in Erzurum Ataturk university refectory. American International Journal of Contemporary Research. 2014;4(1):100-17.

8. Merdol TK. Toplu Beslenme Yapılan Kurumlar için Standart Yemek Tarifeleri. Ankara: Hatiboğlu Yayınevi; 2019.

9. Garg A, Kumar J. Exploring customer satisfaction with university cafeteria food services. An empirical study of Temptation Restaurant at Taylor's University, Malaysia. EJTHR. 2017;8(2):96-106.

10. Tam R, Yassa B, Parker H, O’Connor H, Allman-Farinelli M. University students' on-campus food purchasing behaviors, preferences, and opinions on food availability. Nutrition. 2017;37:7-13.

11. Yükseköğretim Kurulu Uluslararası İlişkiler Daire Başkanlığı - YÖK’ten Üniversitelere "Uluslararası Öğrenci Kontenjanı” Müjdesi. 2019. Available at: https:// uluslararasi.yok.gov.tr/Sayfalar/Haberler/1905/190506Uluslar\%200gr\%20Kont/Uluslar-Ogr-Kont.aspx Accessed Oct 30, 2020.

12. Kusku F. Dimensions of employee satisfaction: A state university example. METU Studies in Development. 2001;28(3/4):399-430.

13. Chen SH, Yang CC, Shiau JY, Wang HH. The development of an employee satisfaction model for higher education. The TQM Magazine. 2006;18(5):484-500.

14. Wanjek C. Food at work: Workplace solutions for malnutrition, obesity and chronic diseases. International Labour Organization; 2005.

15. Dikmen D, Pekcan G. Besin ögesi örüntü profili: Toplu beslenme hizmeti veren kuruluşlarda uygulanan menülerin değerlendirilmesi. Bes Diy Der. 2013;41(3):234-41.

16. Miles MB, Huberman AM, Saldaña J. Qualitative data analysis: A methods sourcebook. 3rd. Thousand Oaks, CA: Sage; 2014.

17. Baysal A, Merdol TK. Toplu Beslenme Yapılan Kurumlar için Yemek Planlama Kuralları ve Yıllık Yemek Listeleri. 4. Baskı. Ankara: Hatiboğlu Yayınevi; 2012.

18. QSR International Pty Ltd. (2018) NVivo (Version 12). 
19. Ebispro for Windows, Stuttgart, Germany; Turkish Version (BeBiS 8.2), Pasifik Elektirik Elektronik Ltd. Şti. (www.bebis.com.tr); Istanbul, 2019.

20. IBM Corp. Released 2017. IBM SPSS Statistics for Windows, Version 25.0. Armonk, NY: IBM Corp.

21. T.C. Sağlık Bakanlığı. Türkiye Beslenme Rehberi (TÜBER). Sağlık Bakanlığı Yayınları, Ankara, 2015.

22. Meyers LD, Hellwig JP, Otten JJ. Dietary reference intakes: the essential guide to nutrient requirements. National Academies Press; 2006.

23. Drewnowski A. The Nutrient Rich Foods Index helps to identify healthy, affordable foods. Am J Clin Nutr. 2010;91(4):1095-101.

24. Halıcı N. Türk Mutfağı'nın Temel Eğitim ve Uygulama Kitabı. İstanbul: Oğlak Yayıncılık ve Reklamcılık Ltd. Şti; 2009.

25. Yona O, Goldsmith R, Endevelt R. Improved meals service and reduced food waste and costs in medical institutions resulting from employment of a food service dietitian - a case study. Isr J Health Policy Res. 2020;9(1):5.

26. Gregoire MB, Lafferty LJ, Dowling RA. Teaching food service management: A critical component in dietetics education. Topics in Clinical Nutrition. 2006;21(3):182-9.

27. Hussain Z. Role of dietitian in a food service industry. Nutri Food Sci Int J. 2017;3(1): 555604.

28. Dhillon J, Diaz Rios LK, Aldaz KJ, De La Cruz N, Vu E, Asad Asghar S, et al. We don't have a lot of healthy options: Food environment perceptions of first-year, minority college students attending a food desert campus. Nutrients. 2019;11(4):816.

29. Ng KW, Sangster J, Priestly J. Assessing the availability, price, nutritional value and consumer views about foods and beverages from vending machines across university campuses in regional New South Wales, Australia. Health Promot J Austr. 2019;30(1):76-82.

30. Gok I, Ulu EK. Functional foods in Turkey: marketing, consumer awareness and regulatory aspects. Nutrition \& Food Science. 2019;49(4):668-86.

31. Gracia A, Barreiro-Hurlé J. Making sense of information overload: Consumer ranking of nutritional claims in cereal based products. Nutrients. 2019;11(12):2858.

32. Grech A, Allman-Farinelli M. A systematic literature review of nutrition interventions in vending machines that encourage consumers to make healthier choices. Obes Rev. 2015;16(12):1030-41.

33. Cadario R, Chandon P. Which healthy eating nudges work best? A meta-analysis of field experiments. Marketing Science. 2020;39(3):465-86.
34. Deliens T, Deforche B, Annemans L, De Bourdeaudhuij I, Clarys P. Effectiveness of pricing strategies on french fries and fruit purchases among university students: results from an on-campus restaurant experiment. PLoS One. 2016;11(11):e0165298.

35. Kwun DJ-W. Effects of campus foodservice attributes on perceived value, satisfaction, and consumer attitude: A gender-difference approach. Int J Hosp Manag. 2011;30(2):252-61.

36. Lachat CK, Huybregts LF, Roberfroid DA, Van Camp J, Remaut-De Winter A-ME, Debruyne P, et al. Nutritional profile of foods offered and consumed in a Belgian university canteen. Public Health Nutr. 2009;12(1):1228.

37. Nelson MC, Kocos R, Lytle LA, Perry CL. Understanding the perceived determinants of weight-related behaviors in late adolescence: A qualitative analysis among college youth. J Nutr Educ Behav. 2009;41(4):287-92.

38. Marquis M. Exploring convenience orientation as a food motivation for college students living in residence halls. Int J Consum Stud. 2005;29(1):55-63.

39. Hilger-Kolb J, Diehl K. 'Oh god, I have to eat something, but where can i get something quickly?'-A qualitative interview study on barriers to healthy eating among university students in Germany. Nutrients. 2019;11(10):2440.

40. Bolek S. Consumer knowledge, attitudes, and judgments about food safety: A consumer analysis. Trends Food Sci Technol. 2020;102:242-8.

41. Sanlier N, Baser F. The relationship among food safety knowledge, attitude, and behavior of young Turkish women. J Am Coll Nutr. 2020;39(3):224-34.

42. Garza-Guerrero AC. Culture shock: Its mourning and the vicissitudes of identity. J Am Psychoanal Assoc. 1974;22(2):408-29.

43. Kalyoncu ZB. Development of A New Scale to Measure Culinary Acculturation of Immigrants Who Are Living in Turkey: Validity and Reliability Assessment. [Ph. D. Thesis]. Hacettepe University Institute of Health Sciences. Ankara; 2018.

44. Unger JB, Reynolds K, Shakib S, Spruijt-Metz D, Sun P, Johnson CA. Acculturation, physical activity, and fastfood consumption among Asian-American and Hispanic adolescents. J Community Health. 2004;29(6):467-81.

45. Amos S, Lordly D. Picture this: a photovoice study of international students' food experience in Canada. Can J Diet Pract Res. 2014;75(2):59-63. 
Appendix 1. Key questions for focus-group discussions

1. Since the subject is quite comprehensive, I would like to present you some photos taken from this university and other universities. Looking at these photos, how healthy do you think the food and beverage services provided at this university are?

2. What are your opinions on price, quality and taste aspects of the food and beverage services provided at this university?

3. What are your opinions on the ideal food environment of a university campus?

4. May I ask you to name three concepts that remained with you from all we talked about during this discussion? 


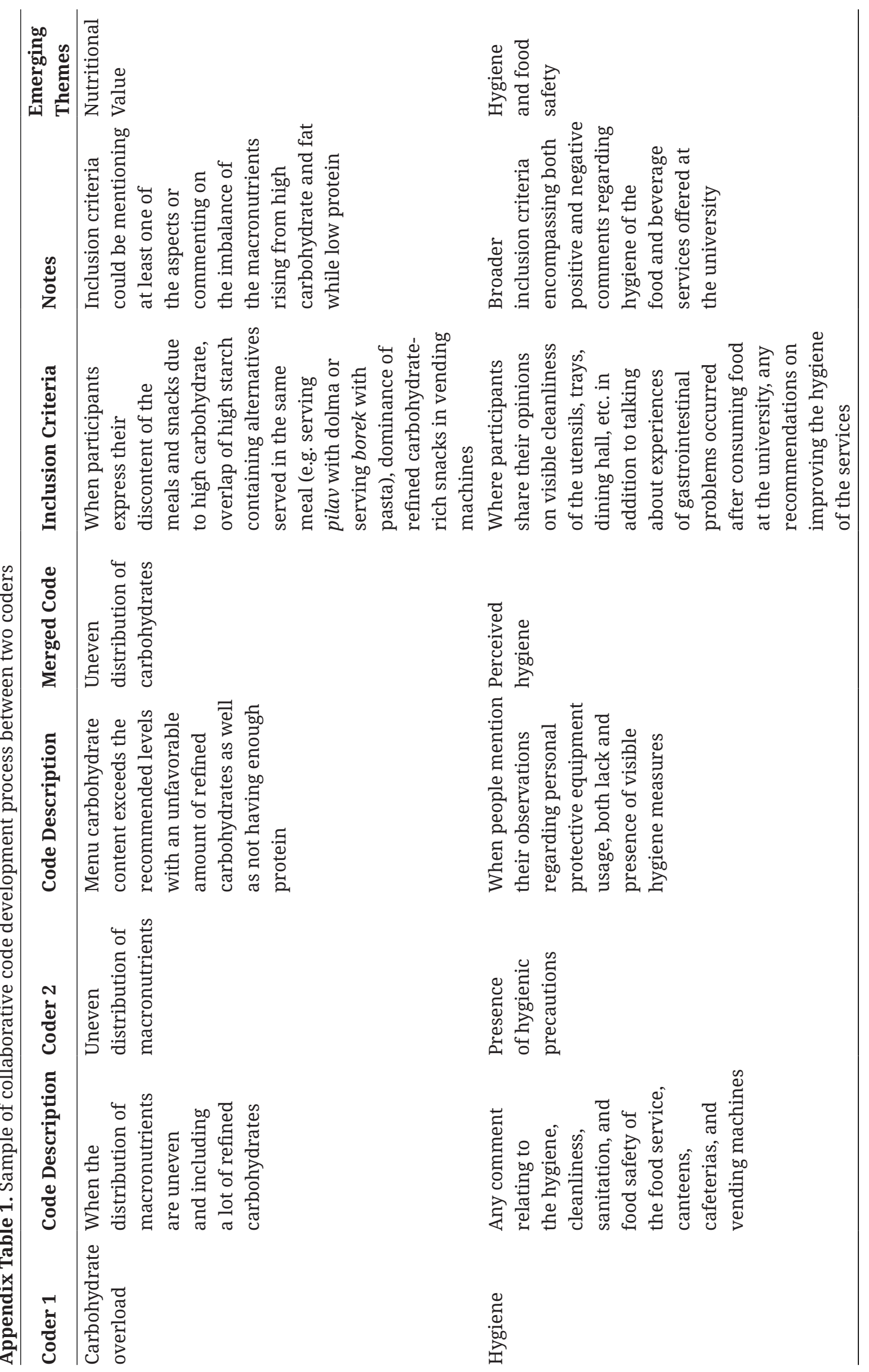




\section{TOTAL}

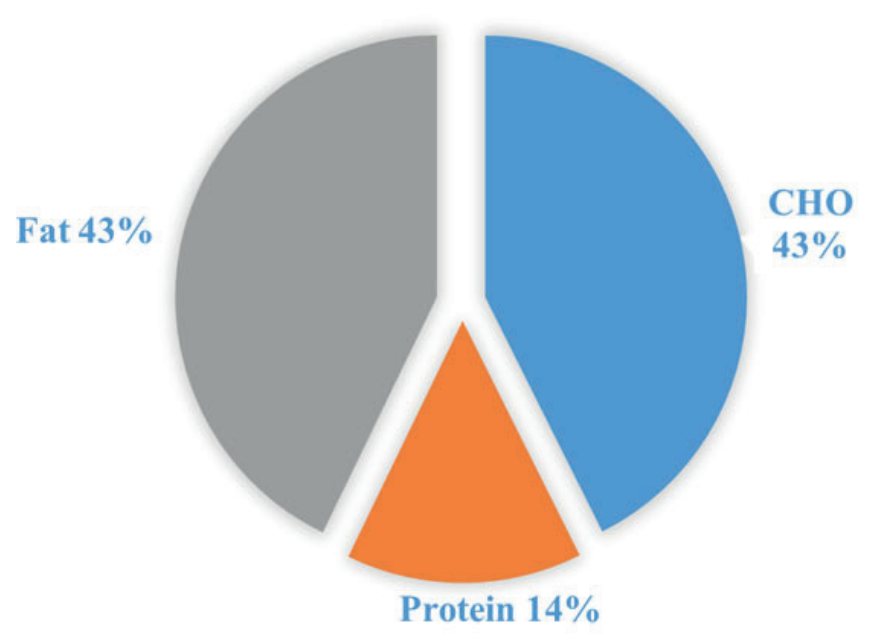

\section{W MEAT}

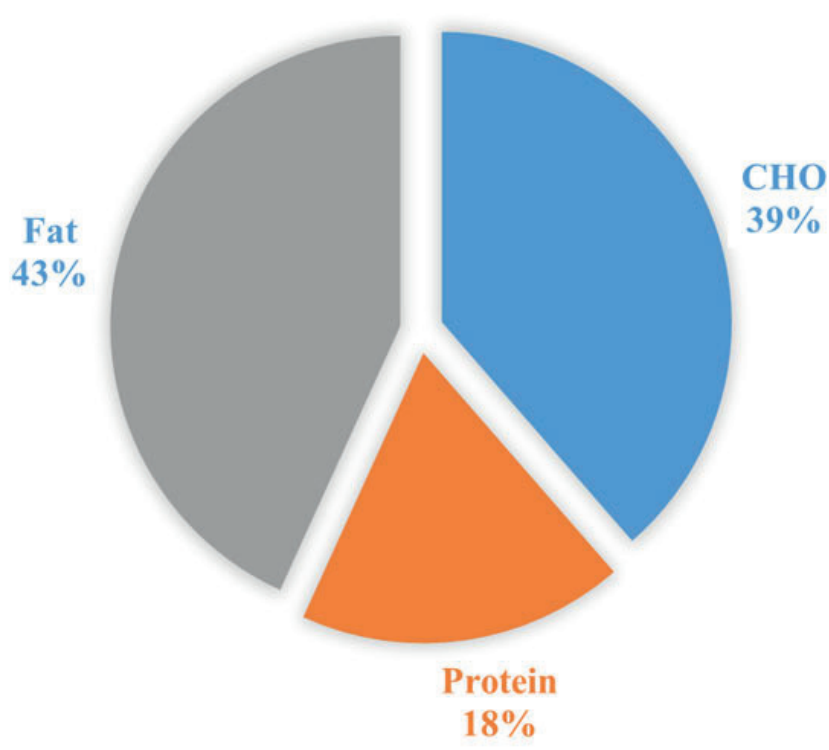

W/O MEAT

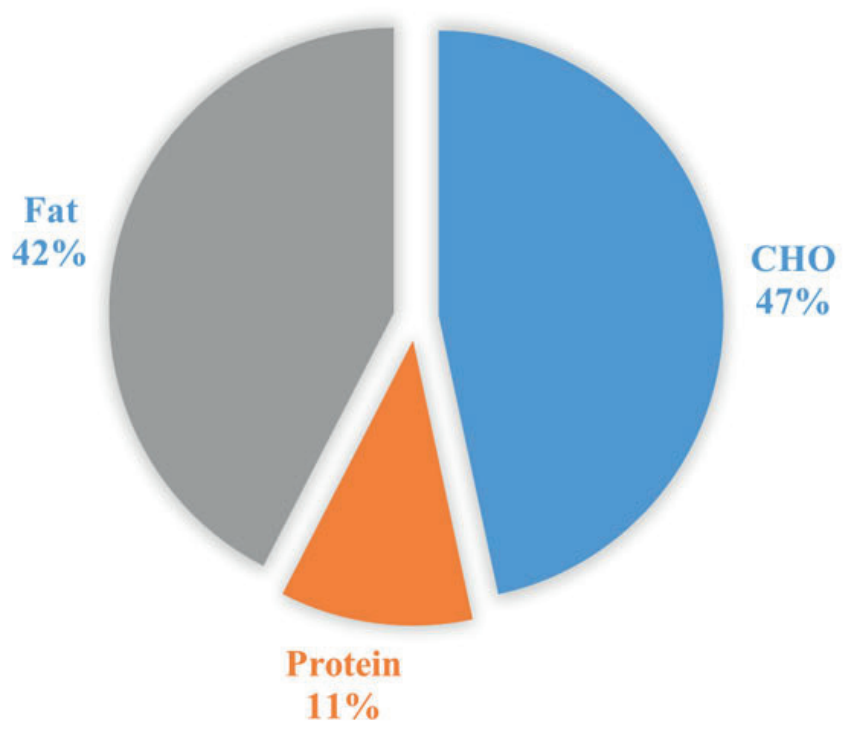

Appendix Figure 1. Macronutrient distribution of the menus W: with W/O: without 


\section{NRF-W SALT}

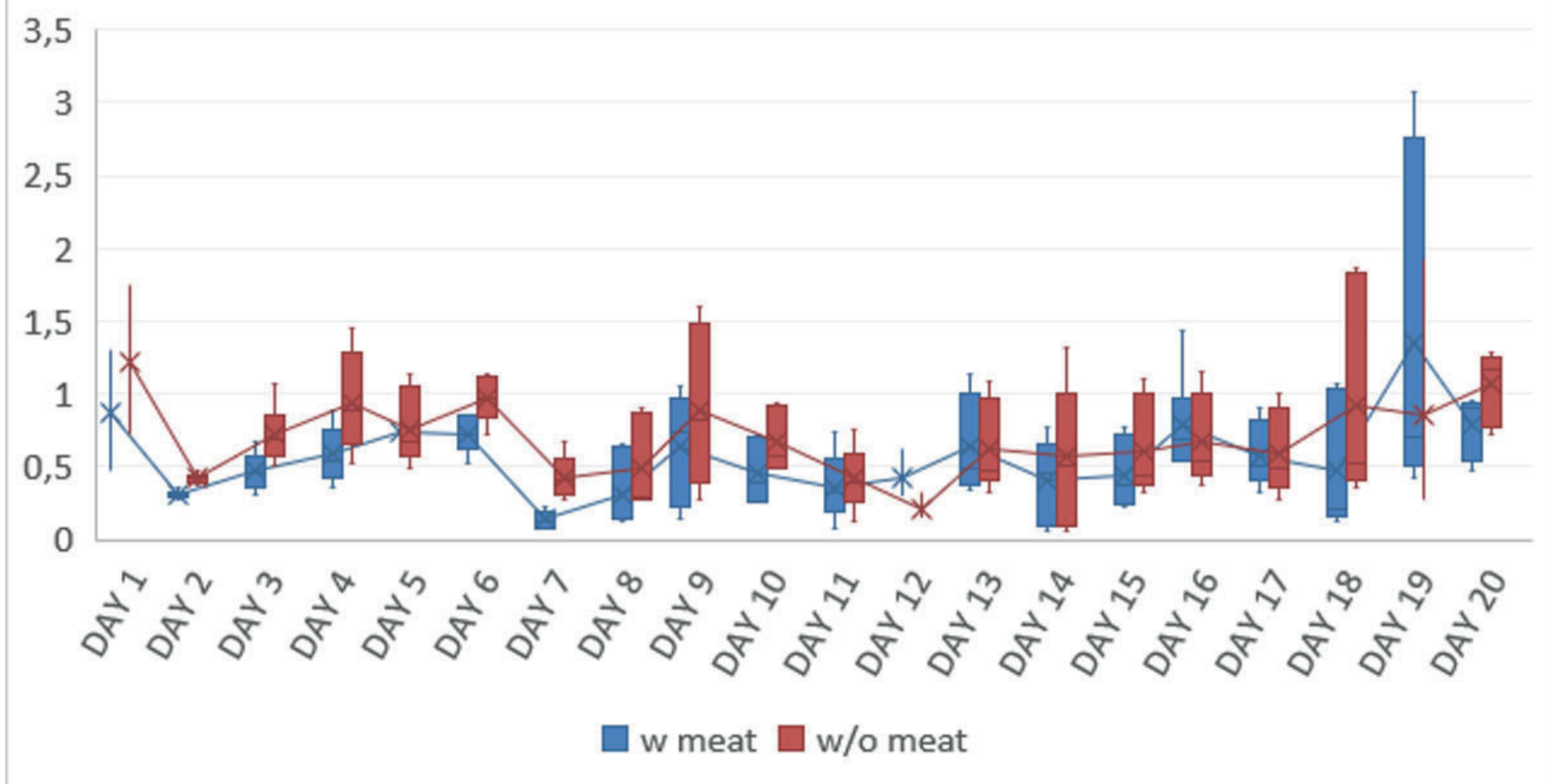

\section{NRF-W/O SALT}

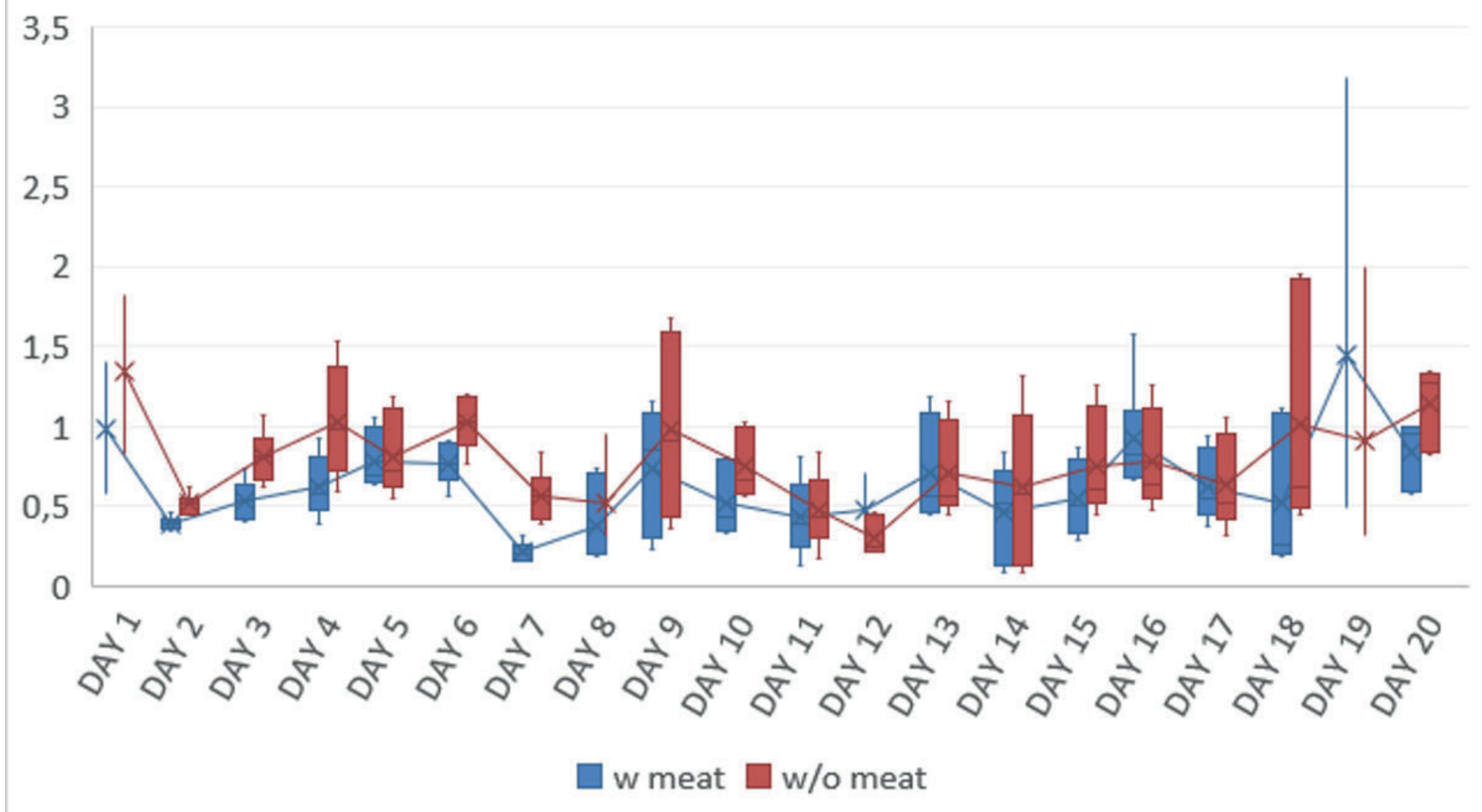

Appendix Figure 2. Boxplots showing the NRF 9.3 scores among the 20 consecutive days 